NBER WORKING PAPER SERIES

\title{
THE IMPACT OF PRE-MARITAL SEX RATIOS ON HOUSEHOLD SAVING IN TWO ASIAN COUNTRIES: \\ THE COMPETITIVE SAVING MOTIVE REVISITED
}

\author{
Charles Yuji Horioka \\ Akiko Terada-Hagiwara \\ Working Paper 22412 \\ http://www.nber.org/papers/w22412
NATIONAL BUREAU OF ECONOMIC RESEARCH
1050 Massachusetts Avenue
Cambridge, MA 02138
July 2016

We thank Jiro Akita, Chetan Ghate, Pedro Gomis-Porqueras, Shikha Jha, Shoshana Grossbard, Tatsuo Hatta, Aziz Hayat, Yoshihiko Kadoya, Takamitsu Kurita, Jaewoo Lee, Seunghwan Leem, Debdulal Mallick, Keunkwan Ryu, Kwanho Shin, Xueli Tang, Hideki Toya, Shinsuke Uchida, Midori Wakabayashi, Junmin Wan, Shang-Jin Wei, Tansel Yilmazer, seminar participants at the Asian Growth Research Institute, Deakin University, Fukuoka University, the International Monetary Fund/Bank of Korea Conference on "Asia: Challenges of Stability and Growth," Korea University, Nagoya City University, Seoul National University, Tohoku University, and the University of the Philippines, Diliman, two anonymous referees, and especially Yoko Niimi for their very helpful comments, Elenita Pura and Shiela Camingue-Romance for superb research assistance, and JSPS KAKENHI Grant Number 15H01950, the Asian Growth Research Institute, and the Joint Usage/Research Center at the Institute of Social and Economic Research, Osaka University, for their financial support. The views expressed in this paper are those of the authors and do not necessarily reflect the views or policies of the Asian Development Bank, its Board of Directors, or the governments they represent. The views expressed herein are those of the authors and do not necessarily reflect the views of the National Bureau of Economic Research.

NBER working papers are circulated for discussion and comment purposes. They have not been peer-reviewed or been subject to the review by the NBER Board of Directors that accompanies official NBER publications.

(C) 2016 by Charles Yuji Horioka and Akiko Terada-Hagiwara. All rights reserved. Short sections of text, not to exceed two paragraphs, may be quoted without explicit permission provided that full credit, including $\odot$ notice, is given to the source. 
The Impact of Pre-marital Sex Ratios on Household Saving in Two Asian Countries: The Competitive Saving Motive Revisited

Charles Yuji Horioka and Akiko Terada-Hagiwara

NBER Working Paper No. 22412

July 2016

JEL No. D12,D14,D91,E21,J11,J12,O16

\begin{abstract}
$\underline{\text { ABSTRACT }}$
This paper estimates a household saving rate equation for India and Korea using long-term time series data for the 1975-2010 period, focusing in particular on the impact of the pre-marital sex ratio on the household saving rate. To summarize the main findings of the paper, it finds that the pre-marital sex (or gender) ratio (the ratio of males to females) has a significant impact on the household saving rate in both India and Korea, even after controlling for the usual suspects such as the aged and youth dependency ratios and income. It has a negative impact in India, where the bride's side has to pay substantial dowries to the groom's side at marriage, but a positive impact in Korea, where, as in China, the groom's side has to bear a disproportionate share of marriagerelated expenses including purchasing a house or condominium for the newlywed couple.
\end{abstract}

Charles Yuji Horioka

Asian Growth Research Institute

11-4, Ohtemachi, Kokurakita-ku

Kitakyushu City, Fukuoka 803-0814

Japan

and NBER

horioka@iser.osaka-u.ac.jp

Akiko Terada-Hagiwara

Macroeconomics Research Division

Economics Research and

Regional Cooperation Department

Asian Development Bank

Manila, Philippines

ahagiwara@adb.org 


\title{
The Impact of Pre-marital Sex Ratios on Household Saving in Two Asian Countries: The Competitive Saving
}

\section{Motive Revisited*}

\author{
Charles Yuji Horioka** and Akiko Terada-Hagiwara***
}

July 5,2016

Abstract: This paper estimates a household saving rate equation for India and Korea using long-term time series data for the 1975-2010 period, focusing in particular on the impact of the pre-marital sex ratio on the household saving rate. To summarize the main findings of the paper, it finds that the pre-marital sex (or gender) ratio (the ratio of males to females) has a significant impact on the household saving rate in both India and Korea, even after controlling for the usual suspects such as the aged and youth dependency ratios and income. It has a negative impact in India, where the bride's side has to pay substantial dowries to the groom's side at marriage, but a positive impact in Korea, where, as in China, the groom's side has to bear a disproportionate share of marriage-related expenses including purchasing a house or condominium for the newlywed couple.

Key words: Age structure of the population; competitive saving motive; dowries; gender ratio; household saving rate; life cycle hypothesis; marriage expenses; pre-marital sex ratio; population control; saving for education; saving for marriage; saving rate; sex ratio; son preference; wedding expenses; Korea; India.

Journal of Economic Literature classification numbers: D12, D14, D91, E21, J11, J12, O16

*We thank Jiro Akita, Chetan Ghate, Pedro Gomis-Porqueras, Shikha Jha, Shoshana Grossbard, Tatsuo Hatta, Aziz Hayat, Yoshihiko Kadoya, Takamitsu Kurita, Jaewoo Lee, Seunghwan Leem, Debdulal Mallick, Keunkwan Ryu, Kwanho Shin, Xueli Tang, Hideki Toya, Shinsuke Uchida, Midori Wakabayashi, Junmin Wan, Shang-Jin Wei, Tansel Yilmazer, seminar participants at the Asian Growth Research Institute, Deakin University, Fukuoka University, the International Monetary Fund/Bank of Korea Conference on "Asia: Challenges of Stability and Growth,” Korea University, Nagoya City University, Seoul National University, Tohoku University, and the University of the Philippines, Diliman, two anonymous referees, and especially Yoko Niimi for their very helpful comments, Elenita Pura and Shiela Camingue-Romance for superb research assistance, and JSPS KAKENHI Grant Number 15H01950, the Asian Growth Research Institute, and the Joint Usage/Research Center at the Institute of Social and Economic Research, Osaka University, for their financial support. The views expressed in this paper are those of the authors and do not necessarily reflect the views or policies of the Asian Development Bank, its Board of Directors, or the governments they represent.

${ }^{* *}$ C. Y. Horioka, Asian Growth Research Institute, 11-4, Ohtemachi, Kokurakita-ku, Kitakyushu, Fukuoka 813-0814, Japan. Email: horioka@iser.osaka-u.ac.jp; National Bureau of Economic Research, Cambridge, MA, USA; Institute of Social and Economic Research, Osaka University, Osaka, Japan

***A. Terada-Hagiwara, Economic Research and Regional Cooperation Department, Asian Development Bank, 6 ADB Avenue, Mandaluyong City, Metro Manila 1550, Philippines. Email: ahagiwara@adb.org 


\section{Introduction}

As documented by Wei and Zhang (2011a), Du and Wei (2013), and Golley and Tyers (2014), the introduction of the one-child policy and other population control measures in the People's Republic of China (hereafter China), combined with strong son preference, led to an increasingly unbalanced sex (or gender) ratio (ratio of males to females) in the pre-marital cohort. And in two widely cited papers, Wei and Zhang (2011a) and Du and Wei (2013) argue that the increasingly unbalanced pre-marital sex ratio, in turn, required the groom's side to save increasingly more to ensure his success in an increasingly competitive marriage market and that this elevated the saving rate of the household sector as a whole (what they call the "competitive saving motive").

Wei and Zhang (2011a) and Du and Wei (2013) verify this effect using household-level data and provincial panel data for China, cross-country data for a sample of about 160 countries, and numerical calibration methods and show that the sharp increase in the pre-marital sex ratio can potentially explain about $60 \%$ of the sharp increase in China's household saving rate during the 1990-2007 period (from 16\% to 30\%) and about half of both the current account surplus of China and the current account deficit of the United States (see Wei and Zhang (2015) for a useful survey).

While the "competitive saving motive" may be applicable outside of China given the unbalanced sex ratios and conventions regarding marriage-related expenses in other countries, empirical investigations have been limited (but see Horioka (1987) for an analysis of saving for marriage in Japan). The purpose of this paper is to contribute to 
the literature by determining whether or not a similar mechanism has led to a significant relationship between the pre-marital sex ratio and the household saving rate in India and the Republic of Korea (hereafter Korea), two countries in which, as in China, sex ratios are unbalanced and marriage-related expenses are considerable, and to determine whether or not trends over time in the pre-marital sex ratio can explain trends over time in the household saving rate in these two countries. In order to accomplish these objectives, this paper estimates a household saving rate equation for India and Korea using long-term time series data for the 1975-2010 period, focusing in particular on the impact of the pre-marital sex ratio on the household saving rate.

To summarize the main findings of this paper, it finds that the pre-marital sex ratio (ratio of males to females) has a significant impact on the household saving rate in India and Korea, even after controlling for the usual suspects such as the aged and youth dependency ratios and income. It has a negative impact in India, where the bride's side has to pay substantial dowries to the groom's side at marriage, but a positive impact in Korea, where, as in China, the groom's side has to bear a disproportionate share of marriage-related expenses including purchasing a house or condominium for the newlywed couple. The findings of the paper imply that trends in the pre-marital sex ratio can explain trends in the household saving rate during the first half of the sample period but not during the second half in both countries and that the level of the pre-marital sex ratio can partly explain the high level of Korea's household saving rate but not the high level of India's household saving rate. 
The remainder of this paper is organized as follows: Section 2 contains a theoretical discussion of the impact of the pre-marital sex ratio on the household saving rate, section 3 presents and discusses data on trends over time in the pre-marital sex ratio and the household saving rate in India and Korea, section 4 presents the estimation model used in this paper, section 5 discusses the data sources used, section 6 presents the estimation results, and section 7 summarizes, concludes, and explores the policy implications of our findings.

\section{Theoretical Considerations}

In this section, we discuss the theoretical impact of the sex (male-to-female) ratio of the pre-marital cohort on the household saving rate (this exposition is based on Grossbard-Shechtman (1993), Wei and Zhang (2011a), Du and Wei (2013), and Grossbard (2015)). ${ }^{1}$ If the pre-marital sex ratio is unbalanced, families with a child who belongs to the overrepresented gender will presumably increase their saving in order to ensure that their child is able to secure an "attractive" spouse, especially if the custom in that country is for families with a child who belongs to the overrepresented gender to bear a disproportionate share of marriage-related expenses. At the same time, families with a child who belongs to the underrepresented gender may or may not reduce their saving due to the presence of two mutually offsetting effects. On the one hand, they may reduce their saving because of their favorable bargaining position in the marriage market, but on the other hand, they may increase their saving to ensure that their child does not suffer an

\footnotetext{
1 See Lafortune (2013) for a very similar analysis of the impact of sex ratios not on the household saving rate but on pre-marital educational investments and Wei and Zhang (2011b) for a very similar analysis of the impact of sex ratios on the occupational choice of parents.
} 
erosion of his or her bargaining power vis-à-vis his or her spouse (assuming that the relative wealth levels of the two sides affects the relative bargaining power of the husband and wife vis-à-vis one other after marriage). Thus, families with a child who belongs to the overrepresented gender will unambiguously increase their saving, but it is not immediately clear whether families with a child who belongs to the underrepresented gender will increase or decrease their saving and whether the saving of the household sector as a whole will increase or decrease, on balance.

However, Du and Wei (2013) show that a higher pre-marital sex ratio will unambiguously raise the saving rate of the household sector as a whole for at least two reasons. First, families with a child who belongs to the overrepresented gender will save more not only because of the child's disadvantaged position in the marriage market but also because they know that families with a child who belongs to the underrepresented gender will save less due to the child's advantaged position in the marriage market and want to compensate for the reduced saving from the other side. Thus, the increase in the saving of families with a child who belongs to the overrepresented gender will more than offset the decrease in the saving of families with a child who belongs to the underrepresented gender. Second, the more unbalanced the pre-marital sex ratio is, the higher will be the proportion of the pre-marital cohort that needs to save more for marriage due to its disadvantaged position in the marriage market.

These theoretical considerations generate the prediction that the saving rate of the household sector as a whole will be lowest when the pre-marital sex ratio is balanced and that it will be higher, the more the pre-marital sex ratio is unbalanced in either direction. 
In other words, the pre-marital sex ratio will have a negative impact on the household saving rate if the pre-marital sex ratio is below the biologically normal sex ratio of 1.05 to 1.06 and a positive impact on the household saving rate if the pre-marital sex ratio is above this threshold. However, as shown later, the pre-marital sex ratio is unbalanced in favor of males (exceeds the 1.06 threshold) in both India and Korea (except in Korea during the 1975-1983 period). This implies that we would expect the pre-marital sex ratio to have a positive impact on the household saving rate in both countries because the groom's side will have to save more and more as the pre-marital sex ratio increases and brides become in increasingly short supply.

However, the foregoing discussion ignores the issue of which side bears the brunt of marriage-related expenses, and it is to this issue that we now turn. Since the custom in China is for the groom's side to bear a disproportionate share of marriage-related expenses including purchasing a house or condominium for the newlywed couple, this in turn bid up the cost of securing a bride, led families with sons to save more than before, and caused the overall household saving rate to increase over time. Similarly, in the case of Korea, the bride's side is expected to pay a (cash) dowry and to pay for the furnishings of the newlywed's home, but the groom's side is expected to return half of the dowry and to pay for the newlywed's home, which has become a more and more onerous burden over time due to the rapid rise in housing prices (see Onishi (2007)). Thus, wedding customs in Korea are very similar to those in China, with the groom's side being expected to bear a disproportionate share of marriage-related expenses, and moreover, housing prices have increased sharply in Korea, as they have in China, thereby further increasing the groom 
side's burden. ${ }^{2}$

By contrast, in the case of India, the bride's side must pay enormous dowries to the groom's side. According to Anderson (2007), dowries are paid in 93 to $94 \%$ of cases in India and amount to 4 to 6 times annual male income, 7 to 8 times annual per capita income, and $68 \%$ of total household assets before marriage, and the amount of dowries increased at the phenomenal rate of 15\% per year during the 60-year from 1921 until 1981. The Dowry Prohibition Act was enacted in 1961 and it was further strengthened in 1983 and 2005, but the payment of dowries is still common in many parts of India and the aforementioned laws are primarily concerned with preventing and punishing the cruel treatment, harassment, and even murder of brides in connection with dowry demands rather than with the payment of the dowry itself. Thus, the situation in India is the opposite of that in China.

If the social custom is for the groom's side to bear a disproportionate share of marriage-related expenses (as in China and Korea), the positive impact of the pre-marital sex ratio on the household saving rate will be actualized because the groom's side has to save for marriage-related expenses even when the pre-marital sex ratio is balanced and will have to save even more for marriage-related expenses if the pre-marital sex ratio is unbalanced and they are disadvantaged in the marriage market.

By contrast, if the social custom is for the bride's side to bear a disproportionate share of

\footnotetext{
${ }^{2}$ Note, however, that there is an endogeneity issue here, with the higher housing prices in China and Korea being caused in part by the increased demand for housing caused by the unbalanced pre-marital sex ratio (see, example, Wei, Zhang, and Liu, 2015).
} 
marriage-related expenses (as in India), the positive impact of the pre-marital sex ratio on the household saving rate may not be actualized because it is the bride's side that bears the burden of marriage-related expenses, and even if the pre-marital sex ratio increases (the ratio of grooms to brides increases), the groom's side will not necessarily have to save any more than before for marriage-related expenses despite their disadvantaged position in the marriage market. Indeed, as the pre-marital sex ratio increases, the shortage of brides will become increasingly acute, which in turn might bid down dowries, reduce the marriage-related saving that the bride's side has to do, and thereby reduce overall household saving. Thus, the impact of the pre-marital sex ratio on the household saving rate is theoretically ambiguous, but it could well have a negative impact on the household saving rate, the opposite result from countries such as China and Korea where the groom's side bears a disproportionate share of marriage-related expenses.

To summarize, even though the pre-marital sex ratio is unbalanced in favor of males in both India and Korea, we would expect the impact of the pre-marital sex ratio to be different in the two countries due the differences in social customs regarding which side bears the brunt of marriage-related expenses. We would expect the pre-marital sex ratio to have a positive impact on the household saving rate in Korea where the groom's side bears a disproportionate share of marriage-related expenses, and it could well have a negative impact on the household saving rate in India, where the bride's side bears a disproportionate share of marriage-related expenses. 


\section{Data on Pre-Marital Sex Ratios and Household Saving Rates in India and Korea}

In this section, we present data on the sex ratio of the pre-marital cohort and the household saving rate in India and Korea during the 1975-2010 period.

In India, the average age at first marriage was 22.7 for males, 17.7 for females, and 20.2 for both sexes in 1971 and 26.0 for males, 22.2 for females, and 24.1 for both sexes in 2011 (all data were taken from Medindia, 2016), and thus the average age at first marriage for both sexes presumably averaged about 22 during the 1975-2010 period as a whole. By contrast, in Korea, the average age at first marriage was much later--26.7 for males, 22.8 for females, and 24.75 for both sexes in 1966 and 32.2 for males, 29.6 for females, and 30.9 for both sexes in Korea in 2013 (the data for 1966 were taken from Lapierre-Adamcyk and Burch (1974) while the data for 2013 were taken from Statistics Korea (2013)), and thus the average age at first marriage for both sexes presumably averaged about 28 during the 1975-2010 period as a whole. We therefore define the pre-marital cohort as the 10 to 19 age group in India and the 15 to 24 age group in Korea, reflecting differences in the average age at first marriage in the two countries, and calculate SEXRATIO (the sex ratio of the pre-marital cohort) as the ratio of males to females for the 10 to 19 age group in the case of India and for the 15 to 24 age group in the case of Korea. It would have been preferable to use a different definition of the pre-marital cohort in each year to reflect increases over time in the average age at first marriage in the two countries, but we were not able to do so because the population data are available only for 5-year age groups. Moreover, it would have been preferable to take account of the age difference between males and females at first marriage (about 4 to 5 years in India and about 3 to 4 years in 
Korea), but we were not able to do so for the same reason.

Figures 1-1 and 1-2 show data on trends over time in SEXRATIO (the pre-marital sex ratio, the ratio of males to females) in India and Korea, respectively, during the 1975-2010 period, taken from United Nations (2016), and as can be seen from these figures, this ratio was relatively stable in India during this period, fluctuating in the 1.080 to 1.103 range. It showed a slight downward trend during the 1975-93 period, declining from 1.094 in 1975 to 1.080 in 1993 , remained stable at 1.080 during the $1993-98$ period, and showed a slight upward trend during the 1998-2010 period, increasing from 1.080 in 1998 to 1.103 in 2010. In Korea, by contrast, the pre-marital sex ratio showed a sharp upward trend throughout the $1975-2010$ period, increasing from 1.045 in 1975 to 1.127 in 2010 . There are at least two possible explanations for this trend. One is the increasing availability and/or affordability of sex determination technology (ultrasonography and amniocentesis) and sex-selective abortions (see Guilmoto (2009) and Du and Wei (2013)), and the other is that the sharp decline in fertility, combined with strong son preference, caused parents to care more about the gender of any given child (see Golley and Tyers (2012) for a discussion of the population control policies that were largely responsible for the sharp decline in fertility).

Note that the biologically normal sex ratio at birth is 1.05 to 1.06 (105 or 106 males for every 100 females). Thus, the sex ratio in both India and Korea is higher than the natural ratio (except until 1983 in Korea), as it is in many, if not most, Asian countries (see Guilmoto (2009) for comparative data on sex ratios at birth for a large number of Asian countries), suggesting that parents have a strong preference for sons in both countries. 
Parents presumably operationalized their preference for sons via female infanticide in earlier times (observed in some northern Indian states such as Delhi, Haryana, and Rajasthan) and by sex-selective abortions (made possible by sex determination technology such as ultrasonography and amniocentesis) in more recent times. ${ }^{3}$ The crucial difference between India and Korea is in trends over time, with Korea showing a much more pronounced upward trend in its sex ratio throughout the period of analysis for the reasons noted earlier.

Turning to data on the household saving rate, we defined HHSR (the household saving rate) as the ratio of net household saving to net household disposable income, where net household saving is calculated as the difference between net household disposable income and household consumption) (see section 5 for data sources). Figures 2-1 and 2-2 show data on HHSR for India and Korea, respectively, during the 1975-2010 period, and as can be seen from these figures, India's household saving rate has shown a long-term upward trend over time, increasing from $9.6 \%$ in 1975 to $26.9 \%$ in 2010 . By contrast, Korea's household saving rate has been highly volatile over time, fluctuating between $0.4 \%$ in 2002 and $26.0 \%$ in 1988 but generally high (above 10\%) until 1999 and generally low (below 10\%) thereafter.

We now compare trends over time in the pre-marital sex ratio to trends over time in the household saving rate in India and Korea. In the case of India, the pre-marital sex ratio and the household saving rate showed opposite trends during the 1975-96 period, with the

\footnotetext{
3 Indeed, Chen, et al. (2013) find using variations across counties in China that access to ultrasound had a significant impact on sex ratios at birth, with $40-50 \%$ of the increase in sex ratios at birth in China being due to improved access to ultrasound.
} 
former showing a downward trend and the latter showing an upward trend, whereas they showed similar trends during the 1996-2010 period, with both of them showing upward trends. Since we hypothesized that the pre-marital sex ratio may have a negative impact on the household saving rate in the case of India, trends in the pre-marital sex ratio may be able to explain trends in the household saving rate during the 1975-96 period but not during the 1996-2010 period.

In the case of Korea, the pre-marital sex ratio showed an upward trend throughout the 1975-2010 period but the household saving rate was volatile during this period. Since we hypothesized that the pre-marital sex ratio will have a positive impact on the household saving rate in the case of Korea and since the household saving rate showed an upward trend during the 1975-78, 1980-88, 1997-98, 2002-04, and 2008-09 periods, trends in the pre-marital sex ratio may be able to explain trends in the household saving rate during these periods but not during other periods.

However, we cannot be certain about the impact of the pre-marital sex ratio on the household saving rate in the two countries unless we conduct a rigorous regression analysis and control for the impact of other factors. It is to this type of analysis that we turn in the remainder of this paper.

\section{Estimation Model}

In this section, we discuss the estimation model we use in our econometric analysis of the determinants of household saving rates in Korea and India. We start with the most 
commonly used specification deriving from the life cycle/permanent income hypothesis that posits that the household saving rate is a function of the age structure of the population, income levels, corporate saving, etc. and add to it the pre-marital sex ratio (see, for example, Modigliani (1970), Feldstein (1977, 1980), Modigliani and Sterling (1983), Horioka (1989, 1997), Edwards (1996), Higgins (1998), Loayza, et al. (2000), Chinn and Prasad (2003), Luhrman (2003), Bosworth and Chodorow-Reich (2007), Horioka and Wan (2007), Kim and Lee (2008), Park and Shin (2009), and Horioka and Terada-Hagiwara (2012) for more details; Fafchamps and Pender (1997), Kochar (1999), and Athukorala and Sen (2004) for papers on India; and Hurd (1995), Kwack and Lee (2005), and Park and Rhee (2005) for papers on Korea).

Thus, the estimation model we use is as follows:

$$
\operatorname{HHSR}(\mathrm{t})=\mathrm{a} 0+\mathrm{a} 1 * \operatorname{DEP}(\mathrm{t})+\mathrm{a} 2 * \operatorname{AGE}(\mathrm{t})+\mathrm{a} 3 * \operatorname{SEXRATIO}(\mathrm{t})+\mathrm{a} 4 * \operatorname{PCY}(\mathrm{t})+
$$
$\mathrm{a} 5 * \operatorname{CORPSAV}(\mathrm{t})+\mathrm{a} 6^{*} \operatorname{POP} 1519(\mathrm{t})+\mathrm{a} 7{ }^{*} \operatorname{TREND}(\mathrm{t})+\mathrm{e}(\mathrm{t})$

where HHSR = the household saving rate (defined as the ratio of net household saving to net household disposable income)

$\mathrm{DEP}=$ the youth dependency ratio, defined as the ratio of the young population (the population aged 0 to 14 in the case of India and the population aged 0 to 19 in the case of Korea) to the working-age population (the population aged 15 to 59 in the case of India and the population aged 20 to 64 in the case of Korea)

$\mathrm{AGE}=$ the aged dependency ratio, defined as the ratio of the aged population (the population aged 60 and older in the case of India and the population aged 65 and older in 
the case of Korea) to the working-age population

SEXRATIO $=$ the sex ratio (the ratio of males to females) of the pre-marital cohort (defined as the 10 to 19 age group in India and the 15 to 24 age group in Korea, for the reasons explained earlier).

PCY $=$ per capita real net household disposable income

CORPSAV $=$ the ratio of net corporate saving to net household disposable income

POP1519 = the ratio of the pre-college population (the population aged 15 to 19 ) to the working-age population (the population aged 20 to 64) (included only in the case of Korea for the reasons given below)

TREND $=$ a time trend

$\mathrm{e}=$ an error term

DEP and AGE are meant to capture the impact of the age structure of the population and are included in virtually all aggregate saving rate regressions. The life cycle hypothesis predicts that both coefficients will be negative since the aggregate household saving rate should be lower, the higher is the ratio of the dependent (young or aged) population to the working-age population. The dependent and working-age populations are defined differently in India and Korea to reflect differences in college entrance rates (higher in Korea than in India) and retirement ages (later in Korea than in India).

Turning to the other explanatory variables, one would expect the coefficient of PCY to be positive since households should be able to afford to save more if their income levels are higher, and one would expect the coefficient of CORPSAV to be negative if households see through the corporate veil and reduce their own saving in response to increases in 
corporate saving.

Yet another demographic variable of possible importance in societies that place value on education is POP1519 (the ratio of pre-college children (the population aged 15 to 19) to the working-age population (the population aged 20 to 64)). More specifically, in a society in which college expenses are high, one would expect parents with pre-college children to save for their children's college expenses and therefore that the aggregate household saving rate will be higher, the higher is the share of parents with pre-college children. By contrast, in a society in which pre-college expenses such as the expenses of cram schools, private tutoring, etc., are high, one would expect parents with pre-college children to have to draw down their savings in order to pay for such expenses and therefore that the aggregate household saving rate will be lower, the higher is the share of parents with pre-college children (see Horioka (1985) for an analysis of saving for education in Japan). This variable was included only in the case of Korea because its coefficient was not significant when included in the regressions for India, perhaps because educational expenses are not as important in India as they are in Korea, which in turn may be due partly to the fact that the practice of sending pre-college students to cram schools, hiring private tutors for them, etc., is far less common in India and partly to the fact that a much lower proportion of the young go to college in India. ${ }^{4}$ As of $2010,39.8 \%$ of the population aged 25 and above had completed tertiary level education in Korea whereas the corresponding figure for India was still only $9.1 \%$, according to data from Barro and Lee (2016).

\footnotetext{
${ }^{4}$ The regression results for India with the POP1519 variable included are available upon request from the authors.
} 


\section{Data Sources}

In this section, we describe the data sources from which our data were taken.

National accounts data for Korea on the net saving and net disposable income of households and non-profit institutions serving households and net corporate saving (needed to calculate HHSR, PCY, and CORPSAV) were taken from Organisation for Economic Co-operation and Development (2016), while similar data for India were taken from CEIC data manager, WEB (New York, N.Y.), which in turn were taken from Central Statistics Office (2016).

In both countries, PCY was calculated by dividing net household disposable income by total population, then deflating by the price deflator for private consumption expenditure. In the case of India, the price deflator was obtained by dividing nominal private consumption expenditure by real private consumption expenditure using data from Central Statistics Office (2016). In the case of Korea, the price deflator was taken directly from Organisation for Economic Co-operation and Development (2016).

DEP, AGE, SEXRATIO, and POP1519 were calculated using data taken from United Nations (2016). 


\section{Estimation Results}

In this section, we present our estimation results.

\subsection{Time Series Properties of the Variables}

We tested the variables used in our analysis for unit roots using the Dickey-Fuller test, Augmented Dickey-Fuller test, KPSS test, and Zivot-Harvey test (see Dickey and Fuller (1979), Kwiatkowski, et al. (1992), Zivot and Andrews (1992), and Harvey, Leybourne, and Taylor (2013)). The detailed test results are not shown due to space limitations, but we found that all of the variables used in our analysis are non-stationary. In particular, most or all tests showed that HHSR, PCY, and CORPSAV are I(1) and that DEP, AGE, SEXRATIO, and CREDIT are I(2) or I(3) in the case of India. Similarly, most or all tests showed that HHSR, CORPSAV, and CREDIT are I(1), that SEXRATIO and FINA are I(1) or I(2), that DEP and AGE are I(2) or I(3), and that the degrees of integration of PCY and POP1519 are not clear in the case of Korea. Thus, there is a real danger that ordinary least squares will lead to spurious correlations, and the use of cointegration techniques is clearly warranted.

\subsection{Results of the Tests for Cointegration}

We tested for cointegration using the Engle-Granger test (Engle and Granger (1987)), the KPSS test (Kwiatkowski, et al. (1992)), and the Johansen test (Johansen $(1988,1991)$ and Johansen and Juselius (1990)). Looking first at the results of the Engle-Granger test and 
the KPSS test (see Tables 1-1 and 1-2), the results for all specifications for both countries indicate the presence of cointegration, implying the presence of a long-term relationship among the variables.

Turning to the results of the Johansen test (not shown due to space limitations), the trace test as well as the maximum eigenvalue test indicate the presence of cointegration in both countries for all specifications. As for the number of cointegrating vectors, the trace test as well as the maximum eigenvalue test indicate the presence of 2 to 5 cointegrating vectors in the case of India and 2 to 4 cointegrating vectors in the case of Korea. A priori we would expect to find only one cointegrating vector and it is well-known that the Johansen test will lead to an upward bias in cointegrating rank in small samples (see, for example, Cheung and Lai (1993) and Johansen (2002)). Thus, when estimating the cointegrating vector, we constrained the number of vectors to be one.

\subsection{The Determinants of Household Saving Rates in India and Korea}

In this subsection, we present our estimates of the cointegrating vector, which shed light on the determinants of the household saving rate in India and Korea. The results for India are shown in Table 2-1, and as can be seen from this table, the coefficient of SEXRATIO is negative and significant in both variants, as expected. As for the coefficients of the other variables, the coefficients of AGE and DEP are negative and significant, as predicted by the life cycle hypothesis, the coefficient of PCY is positive and

significant, as expected, the coefficient of CORPSAV is negative and significant, as expected, and the coefficient of TREND is negative and significant, indicating a downward 
trend in the household saving rate.

The results for Korea are shown in Table 2-2, and as can be seen from this table, the coefficient of SEXRATIO is positive and significant in every variant, as expected. As for the coefficients of the other variables, the coefficient of DEP is always negative and significant, as expected, but the coefficient of AGE is always positive and significant in all but one variant, contrary to expectation. Perhaps this is because Koreans continue to save even after retirement because they are risk-averse (and concerned in particular about longevity risk) and/or because they want to leave a bequest to their children. The coefficient of PCY is positive and significant, as expected, the coefficient of CORPSAV is positive and significant, contrary to expectation, the coefficient of POP1519 is negative and significant, presumably because the cost of cram schools, private tutoring, and other expenses of pre-college students lowers the saving rate of households with pre-college children, and the coefficient of TREND is negative and significant, indicating a downward trend in the household saving rate.

Thus, the results are highly satisfactory, in general, and provide support for the life cycle hypothesis in both India and Korea, and in particular, the coefficient of SEXRATIO has the expected sign (negative in India and positive in Korea) and is always significant in both countries. This suggests that the "competitive saving hypothesis" of Wei and Zhang (2011a) and Du and Wei (2013) applies not only in China but also in India and Korea and that unbalanced pre-marital sex ratios elevate the household saving rate.

We turn now to the implications of our findings for whether trends over time in the 
pre-marital sex ratio can explain trends over time in the household saving rate in India and Korea. Looking first at the case of India, the negative impact of the pre-marital sex ratio on the household saving rate implies that the downward trend in the pre-marital sex ratio until 1993 can explain the upward trend in the household saving rate until 1993 but that the upward trend in the pre-marital sex ratio after 1998 cannot explain the continuing upward trend in the household saving rate after $1998 .^{5}$

Looking next at the case of Korea, the positive impact of the pre-marital sex ratio on the household saving rate implies that the upward trend in the pre-marital sex ratio throughout the 1975-2011 period can explain the upward trend in the household saving rate until 1998 but not the downward trend therein after $1998 .{ }^{6}$

Turning next to whether the level of the pre-marital sex ratio can explain the level of the household saving rate in India and Korea, the fact that the pre-marital sex ratio has a negative impact on the household saving rate in India and the fact that the India's pre-marital sex ratio is higher than average imply that India's household saving rate

${ }^{5}$ If the coefficient of the pre-marital sex ratio became positive after 1998, the upward trend in the pre-marital sex ratio after 1998 would be able to explain the upward trend in the household saving rate, but when we tried introducing an interactive term between SEXRATIO and a dummy variable that equals one for all years after 1997 and zero otherwise, we found that the coefficient of SEXRATIO not only remained negative after 1997 but that its absolute magnitude increased even further.

${ }^{6}$ If the coefficient of the pre-marital sex ratio became negative after 1998, the upward trend in the pre-marital sex ratio after 1998 would be able to explain the downward trend in the household saving rate, but when we tried introducing an interactive term between SEXRATIO and a dummy variable that equals one for all years after 1997 and zero otherwise, we found that the coefficient of SEXRATIO not only remained positive after 1997 but that its absolute magnitude increased even further. 
should be lower than average. Thus, India's pre-marital sex ratio cannot explain India's higher than average household saving rate.

Turning to the case of Korea, the fact that the pre-marital sex ratio has a positive impact on the household saving rate and the fact that Korea's pre-marital sex ratio was below average until 1983 and above average thereafter implies that her household saving rate should have been below average until 1983 and above average after 1983 . Thus, the pre-marital sex ratio can explain the high level of Korea's household saving rate during the 1984-2000 period but not the high level thereof before 1984 nor the low level thereof after 2000.

As for the impact of the age structure of the population, since DEP was found to have a negative impact on India's household saving rate, the steady decline in DEP during the period of analysis can help explain the steady increase in India's household saving rate during this period. AGE was also found to have a negative impact on India's household saving rate, but since it increased only slowly during the period of analysis, it did not have an appreciable impact on trends over time in India's household saving rate during this period, and India's household saving rate showed a steady increase despite the slight downward pressure exerted on it by the slow increase in AGE.

In the case of Korea, both DEP and AGE exerted upward pressure on the household saving rate during the period of analysis because DEP declined over time and has a negative impact on the household saving rate while AGE increased over time and has a positive impact on the household saving rate. Thus, trends in the age structure of the population 
can explain the upward trend in Korea's household saving rate during the 1975-78, 1980-88, 1997-98, 2002-04, and 2008-09 periods but cannot explain trends in Korea's household saving rate during other periods. ${ }^{7}$

\section{Conclusions}

In this paper, we estimated a household saving rate equation for India and Korea using long-term time series data for the 1975-2010 period, focusing in particular on the impact of the pre-marital sex (or gender) ratio (the ratio of males to females) on the household saving rate. To summarize the main findings of the paper, it found that the pre-marital sex ratio has a significant impact on the household saving rate in both India and Korea, even after controlling for the usual suspects such as the aged and youth dependency ratios and income. It has a negative impact in India, where the bride's side has to pay substantial dowries to the groom's side at marriage, but a positive impact in Korea, where, as in China, the groom's side has to bear a disproportionate share of marriage-related expenses including purchasing a house or condominium for the newlywed couple. The

\footnotetext{
7 Finally, we estimated an error correction model to analyze the short-run dynamics of household saving behavior. The results are not shown in detail because they were not very satisfactory, but we provide a brief summary here. In the case of India, virtually none of the coefficients including that of the error correction term were significant. In the case of Korea, the coefficient of the error correction term was negative and significant in some cases, indicating some tendency to return to equilibrium after a deviation. None of the other coefficients were consistently significant, and moreover, their signs were almost always contrary to expectation. These results suggest that the variables included in the analysis cannot adequately explain short-run household saving behavior, which is not surprising because most of the variables included in the analysis are variables that would be expected to have a longer-term impact on household saving behavior.
} 
findings of the paper imply that trends in the pre-marital sex ratio can explain trends in the household saving rate during the first half of the sample period but not during the second half in both countries and that the level of the pre-marital sex ratio can partly explain the high level of Korea's household saving rate but not the high level of India's household saving rate.

In sum, unbalanced pre-marital sex ratios combined with excessive and asymmetric marriage-related expenses have distorted the saving behavior of households in both countries. Du and Wei (2013) conduct a welfare analysis using numerical calibration methods and show that, in China, the welfare of males decreases while that of females increases and that social welfare (the sum of the welfare of all males and all females) decreases as the sex ratio increases. Thus, the welfare of males as well as social welfare could be increased by bringing the sex ratio back into balance in Korea, where marriage customs are similar to those in China, and conversely in India, where marriage customs are the opposite of those in China.

Another policy implication relates to saving-investment imbalances and current account imbalances. Wei and Zhang (2011a) and Du and Wei (2013) show that more than half of the increase in China's household saving rate was due to the sharp increase in the pre-marital sex ratio and that about half of China's current account surplus was due to her unbalanced sex ratio. Similarly, saving distortions caused by unbalanced sex ratios may very well affect saving-investment imbalances and current account imbalances in India and Korea as well. 
A related policy implication of our results relate to the so-called worldwide saving glut. Our results imply that the imbalanced sex ratios in India and Korea are causing India's household saving rate to be lower than it would be otherwise and Korea's household saving rate to be higher than it would be otherwise. Thus, the net impact of imbalanced sex ratios on worldwide saving is ambiguous.

Turning finally to how to reduce or eliminate the distortions in household saving behavior caused by unbalanced pre-marital sex ratios in the first place, there are at least 3 possible ways: (1) to eliminate son (or daughter) preference, (2) to relax or abolish population control measures, and (3) to reduce excessive and asymmetric marriage-related expenses.

There is a long tradition of son preference in Asian societies because the eldest son traditionally carries on the family line or the family business, and it is therefore not easy to weaken this long-held tradition. However, Das Gupta, et al. (2009) argues that Korea did precisely that through direct policy measures although Hvistendahl (2011) disputes this claim (see Golley and Tyers (2014)), and thus weakening son preference is a potentially effective way of eliminating the distortions in household saving behavior caused by unbalanced sex ratios.

Turning to population control measures, they have been implemented in many developing countries as a way of keeping population growth down and raising living standards, but the most extreme example is the one-child policy in China (see Golley and Tyers (2012) for an excellent overview of population control measures in China and India). Relaxing or abolishing population control measures would enable parents to have the desired number 
of children and, at the same time, eliminate the distortions in household saving behavior caused by unbalanced sex ratios, thereby enabling two birds to be killed with one stone. The Chinese government's relaxation of its one-child policy in rural areas and certain cities in the early 1980s (see Golley and Tyers (2012)) and its sudden decision to abolish the one-child policy altogether starting in 2016 are examples of policies that weakened or abolished population control measures.

Finally, the marriage customs that led to excessive and asymmetric marriage-related expenses have a long tradition and hence would be hard to change, but abolishing such customs would reduce the financial burden on parents of newlyweds and, at the same time, eliminate the distortions in household saving behavior caused by unbalanced sex ratios, thereby enabling two birds to be killed with one stone. India's efforts to prohibit dowries via legal means is one example of such a policy.

Moreover, policies to weaken son preference and policies to reduce excessive and asymmetric marriage-related expenses would also lead to greater gender equality, which in turn would lead to a decline in sex-selective abortions and infanticide and in the dowry-related harassment and even murder of women, and hence would be beneficial for that reason as well.

Thus, policies to eliminate son (or daughter) preference, to relax or abolish population control measures, and to reduce excessive and asymmetric marriage-related expenses are highly beneficial because they would not only eliminate the distortions in household saving behavior caused by unbalanced sex ratios but also because they would allow 
parents to have the optimal number of children, reduce the financial burden of marriage-related expenses, and achieve greater gender equality. 


\section{References}

Anderson, Siwan (2007), “The Economics of Dowry and Brideprice," Journal of Economic Perspectives, vol. 21, no. 4 (Fall), pp. 151-174.

Athukorala, Prema-Chandra, and Sen, Kunal (2004), "The Determinants of Private Saving in India," World Development, vol. 32, no. 3 (March), pp. 491-503.

Barro, Robert, and Lee, Jong-Wha (2016), Barro-Lee Educational Attainment Dataset. http://barrolee.com. Accessed June 28, 2016.

Bosworth, Barry, and Chodorow-Reich, Gabriel (2007), "Saving and Demographic Change: The Global Dimension," CRR WP 2007-02, Center for Retirement Research, Boston College, Boston, MA, USA.

Central Statistics Office (2016), Sequence of National Accounts India 2012. Ministry of Statistics and Programme Implementation, Government of India.

http://mospi.nic.in/Mospi_New/upload/SNA12.htm. Accessed June 28, 2016.

Chen, Yuyu; Li, Hongbin; and Meng, Lingsheng (2013), "Prenatal Sex Selection and Missing Girls in China: Evidence from the Diffusion of Diagnostic Ultrasound," Journal of Human Resources, vol. 48, no. 1 (January), pp. 36-70.

Cheung, Yin-Wong, and Lai, Kon S. (1993), "Finite-Sample Sizes of Johansen's Likelihood Ratio Tests for Cointegration," Oxford Bulletin of Economics and Statistics, vol. 55, no. 3 (August), pp. 313-328.

Chinn, Menzie D., and Prasad, Eswar S. (2003), "Medium-term Determinants of Current Account in Industrial and Developing Countries: An Empirical Exploration," Journal of International Economics, vol. 59, no. 1 (January), pp. 47-76.

Das Gupta, Monica; Chang, Woojin; and Li, Shuzhuo (2009), "Evidence for an Incipient Decline in the Number of Missing Girls in China and India," Population and Development Review, vol. 35, no. 2 (June), pp. 401-416. 
Dickey, David A., and Fuller, Wayne A. (1979), "Distribution of the Estimators for Autoregressive Time Series with a Unit Root," Journal of the American Statistical Association, vol. 74, no. 366 (June), pp. 427-431.

Du, Qingyuan, and Wei, Shang-Jin (2013), "A Theory of the Competitive Saving Motive," Journal of International Economics, vol. 91, no. 2 (November), pp. 275-289.

Edwards, Sebastian (1996), "Why Are Latin America's Savings Rates So Low? An International Comparative Analysis," Journal of Development Economics, vol. 51, no. 1 (October), pp. 5-44.

Engle, Robert F., and Granger, C. W. J. (1987), "Co-Integration and Error Correction: Representation, Estimation and Testing," Econometrica, vol. 55, no. 2 (March), pp. 251-276.

Fafchamps, Marcel, and Pender, John (1997), "Precautionary Saving, Credit Constraints, and Irreversible Investment: Theory and Evidence from Semiarid India," Journal of Business and Economic Statistics, vol. 15, no. 2, pp. 180-194.

Feldstein, Martin S. (1977), "Social Security and Private Savings: International Evidence in an Extended Life Cycle Model," in Martin S. Feldstein and Robert P. Inman, eds., The Economics of Public Services (An International Economic Association Conference Volume) (London: MacMillan Press Ltd.).

Feldstein, Martin S. (1980), "International Differences in Social Security and Saving," Journal of Public Economics, vol. 14, no. 2 (October), pp 225-244.

Golley, Jane, and Tyers, Rod (2012), "Population Pessimism and Economic Optimism in the Asian Giants," World Economy, vol. 35, no. 11 (November), pp. 1387-1416.

Golley, Jane, and Tyers, Rod (2014), "Gender 'Rebalancing' in China: A Global-Level Analysis," Asian Population Studies, vol. 10, no. 2, pp. 125-143.

Grossbard, Shoshana (2015), The Marriage Motive: A Price Theory of Marriage: How Marriage Markets Affect Employment, Consumption, and Savings. New York, N.Y., USA: Springer Science. 
Grossbard-Shechtman, Shoshana (1993), On the Economics of Marriage: A Theory of Marriage, Labor, and Divorce. Boulder, Colorado, USA: Westview Press.

Guilmoto, Christopher Z. (2009), “The Sex Ratio Transition in Asia,” Population and Development Review, vol. 35, no. 3 (September), pp. 519-549.

Harvey, David I.; Leybourne, Stephen J.; and Taylor, A. M. Robert (2013), “Testing for Unit Roots in the Possible Presence of Multiple Trend Breaks using Minimum Dickey-Fuller Statistics," Journal of Econometrics, vol. 177, no. 2 (December), pp. 265-284.

Higgins, Matthew (1998), "Demography, National Savings, and International Capital Flows," International Economic Review, vol. 39, no. 2 (May), pp. 343-369.

Horioka, Charles Yuji (1985), "The Importance of Saving for Education in Japan," Kyoto University Economic Review, vol. 55, no. 1 (April), pp. 41-78.

Horioka, Charles Yuji (1987), "The Cost of Marriages and Marriage-related Saving in Japan,” Kyoto University Economic Review, vol. 57, no. 1 (April), pp. 47-58.

Horioka, Charles Yuji (1989), “Why Is Japan's Private Saving Rate So High?” in Ryuzo Sato and Takashi Negishi, eds., Developments in Japanese Economics (Tokyo: Academic Press/Harcourt Brace Jovanovich, Publishers), pp. 145-178.

Horioka, Charles Yuji (1997), "A Cointegration Analysis of the Impact of the Age Structure of the Population on the Household Saving Rate in Japan," Review of Economics and Statistics, vol. 79, no. 3 (August), pp. 511-516.

Horioka, Charles Yuji, and Terada-Hagiwara, Akiko (2012), "The Determinants and Long-term Projections of Saving Rates in Developing Asia," Japan and the World Economy, vol. 24, no. 2 (March), pp. 128-137.

Horioka, Charles Yuji, and Wan, Junmin (2007), "The Determinants of Household Saving in China: A Dynamic Panel Analysis of Provincial Data," Journal of Money, Credit and Banking, vol. 39, no. 8 (December), pp. 2077-2096. 
Hurd, Michael D. (1995), "Household Saving Rates in Korea: Evidence on Life-Cycle Consumption Behavior," Journal of the Japanese and International Economies, vol. 9, no. 2 (June), pp. 174-199.

Hvistendahl, Mara (2011), Unnatural Selection: Choosing Boys over Girls and the Consequences of a World Full of Men. New York, N.Y., USA; Public Affairs Press.

Johansen, Soren (1988), "Statistical Analysis of Cointegrating Vectors," Journal of Economics, Dynamics and Control, vol. 12, no. 2/3 (June-September), pp. 231-254.

Johansen, Soren (1991), "Estimation and Hypothesis Testing of Cointegration Vectors in Gaussian Vector Autoregressive Models," Econometrica, vol. 59, no. 6 (November), pp. 1551-1580.

Johansen, Soren (2002), “A Small Sample Correction of the Test for Cointegrating Rank in the Vector Autoregressive Model," Econometrica, vol. 70, no. 5 (September), pp. 1929-1961.

Johansen, Soren, and Juselius, Katarina (1990), "Maximum Likelihood Estimation and Inference on Cointegration — with Applications to the Demand for Money," Oxford Bulletin of Economics and Statistics, vol. 52, no. 2 (May), pp. 169-210.

Kim, Soyoung, and Lee, Jong-Wha (2008), "Demographic Changes, Saving, and Current Account: An Analysis based on a Panel VAR Model," Japan and the World Economy, vol. 20, no. 2 (March), pp. 236-256.

Kochar, Anjini (1999), "Smoothing Consumption by Smoothing Income: Hours-Of-Work Responses to Idiosyncratic Agricultural Shocks in Rural India," Review of Economics and Statistics, vol. 81, no. 1 (February), pp. 50-61.

Kwack, Sung Yeung, and Lee, Young Sun (2005), "What Determines Saving Rates in Korea? The Role of Demography," Journal of Asian Economics, vol. 16, no. 5 (October), pp. 861-873.

Kwiatkowski, Denis; Phillips, Peter C. B.; Schmidt, Peter; and Shin, Yongcheol (1992), "Testing the Null Hypothesis of Stationarity against the Alternative of a Unit Root: How 
Sure Are We That Economic Time Series Have a Unit Root?" Journal of Econometrics, vol. 54, no. 1-3 (October-December), pp. 159-178.

Lafortune, Jeanne (2013), "Making Yourself Attractive: Pre-marital Investments and the Returns to Education in the Marriage Market," American Economic Journal: Applied Economics, vol. 5, no. 2 (April), pp. 151-178.

Lapierre-Adamcyk, Evelyne, and Burch, Thomas K. (1974), "Trends and Differentials in Age at Marriage in Korea," Studies in Family Planning, vol. 5, no. 8 (August), pp. 255-260.

Loayza, Norman; Schmidt-Hebbel, Klaus; and Serven, Luis (2000), "What Drives Private Saving across the World?" Review of Economics and Statistics, vol. 82, no. 2 (May), pp. 165-181.

Luhrman, M (2003), "Demographic Change, Foresight and International Capital Flows," MEA Discussion Paper Series 03038, Mannheim Institute of the Economics of Aging, University of Mannheim, Germany.

MedIndia (2016), "Average Age at Marriage - India," Network for Health. http://www.medindia.net/health_statistics/general/marriageage.asp. Accessed June 28, 2016.

Modigliani, Franco (1970), "The Life-cycle Hypothesis and Intercountry Differences in the Saving Ratio," in W. A. Eltis, M. FG. Scott, and J. N. Wolfe, eds., Induction, Growth, and Trade: Essays in Honour of Sir Roy Harrod (Oxford: Oxford University Press), pp. 197-225.

Modigliani, Franco, and Sterling, Arlie (1983), "Determinants of Private Saving with Special Reference to the Role of Social Security: Cross Country Tests," in Franco Modigliani and Richard Hemming, eds., The Determinants of National Saving and Wealth (Proceedings of a Conference held by the International Economic Association at Bergamo, Italy) (London: Macmillan Press Ltd.).

Onishi, Norimitsu (2007), "In South Korea, Tying the Knot Has Plenty of Strings Attached," New York Times, March 21.

Organisation for Economic Co-operation and Development (OECD) (2016), "National Accounts," OECD.Stat. https://stats.oecd.org/. Accessed June 28, 2016. 
Park, Daukeun Park, and Rhee, Changyong (2005), "Saving, Growth, and Demographic Change in Korea," Journal of the Japanese and International Economies, vol. 19, no. 3 (September), pp. 394-413.

Park, Donghyun, and Shin, Kwanho (2009), "Saving, Investment, and Current Account Surplus in Developing Asia," ADB Economics Working Paper Series no. 158, Asian Development Bank, Manila, Philippines (April).

Statistics Korea (2013), Marriage and Divorce Statistics in 2013. http://kostat.go.kr/portal/eng/pressReleases/1/index.board?bmode=read\&aSeq=327223.

Accessed June 28, 2016.

United Nations (2016), World Population Prospects: The 2012 Revision. Population Estimates and Projections Section, Population Division, Department of Economic and Social Affairs. https://esa.un.org/unpd/wpp/. Accessed June 28, 2016.

Wei, Shang-Jin, and Zhang, Xiaobo (2011a), "The Competitive Saving Motive: Evidence from Rising Sex Ratios and Savings Rates in China," Journal of Political Economy, vol. 119, no. 3 (June), pp. 511-564.

Wei, Shang-Jin, and Zhang, Xiaobo (2011b), "Sex Ratios, Entrepreneurship, and Economic Growth in the People's Republic of China," NBER Working Paper No. 16800, National Bureau of Economic Research, Cambridge, Massachusetts, USA.

Wei, Shang-Jin, and Zhang, Xiaobo (2015), "The Competitive Saving Motive: Concept, Evidence, and Implications," ADB Economics Working Paper No. 465, Asian Development Bank, Manila, Philippines (November).

Wei, Shang-Jin; Zhang, Xiaobo; and Liu, Y. (2015), "Status Competition and Housing Prices," NBER Working Paper No. 18000, National Bureau of Economic Research, Cambridge, MA, USA.

Zivot, Eric, and Andrews, Donald W. K. (1992), "Further Evidence on the Great Crash, the Oil-Price Shock, and the Unit-Root Hypothesis," Journal of Business and Economic Statistics, vol. 10, no. 3 (July), pp. 251-270. 
Figure 1-1: Trends over Time in the Pre-Marital Sex Ratio in India

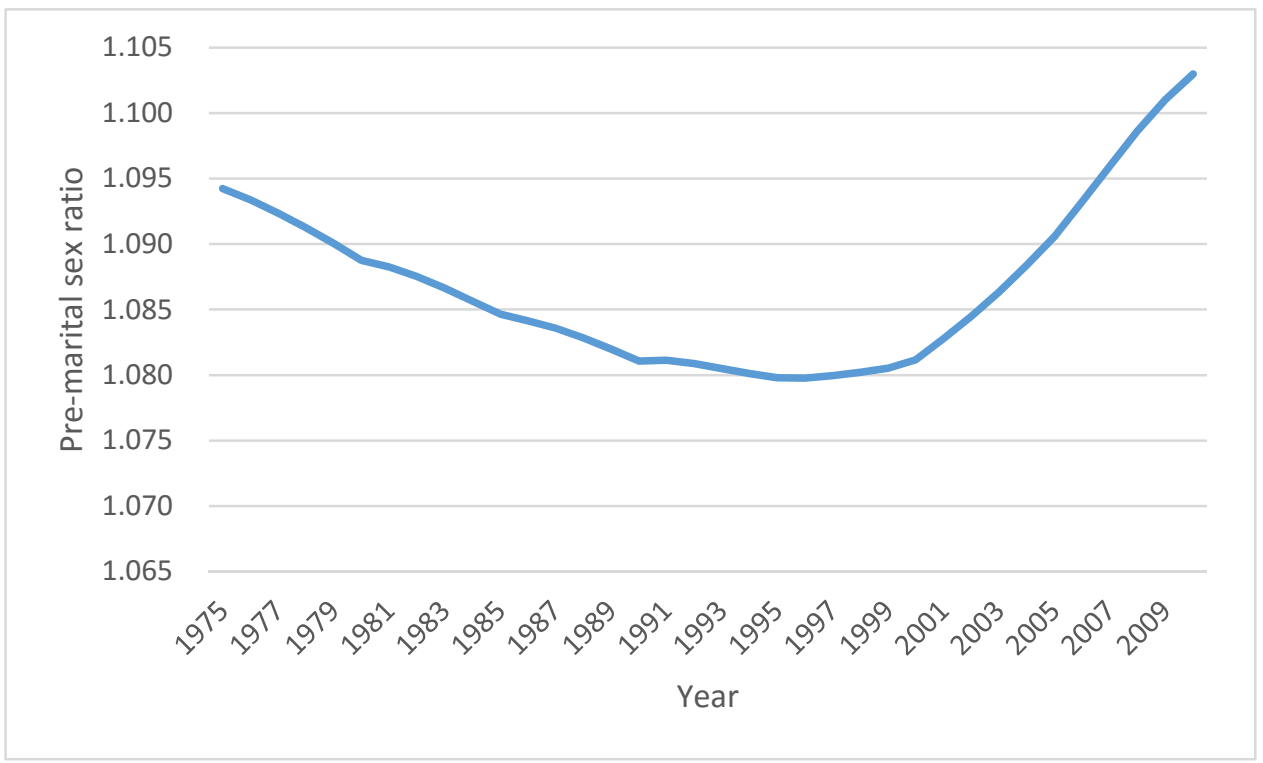

Figure 1-2: Trends over Time in the Pre-Marital Sex Ratio in Korea

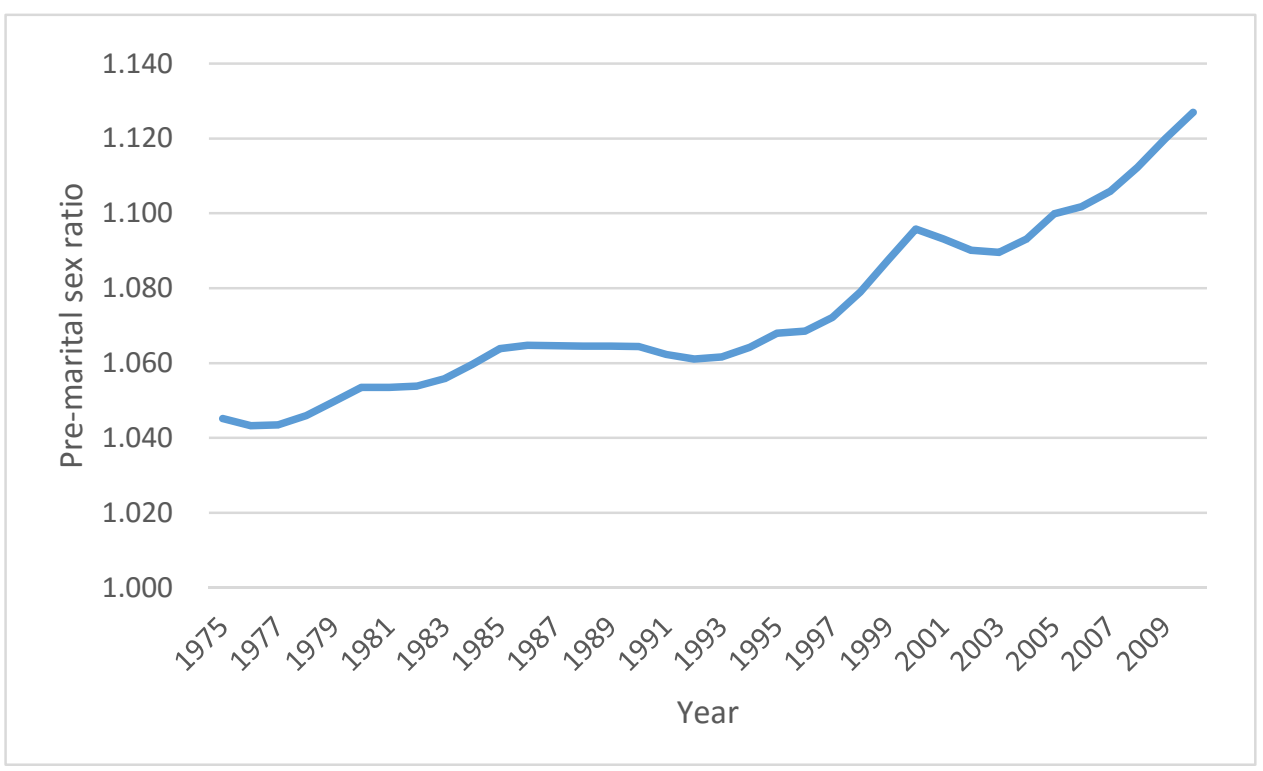

Notes: The pre-marital sex ratio is calculated as the ratio of males to females in the pre-marital cohort (defined as the 10-19 age group in the case of India and the 15-24 age group in the case of Korea). The data are taken from United Nations (2016). 
Figure 2-1: Trends over Time in the Household Saving Rate in India

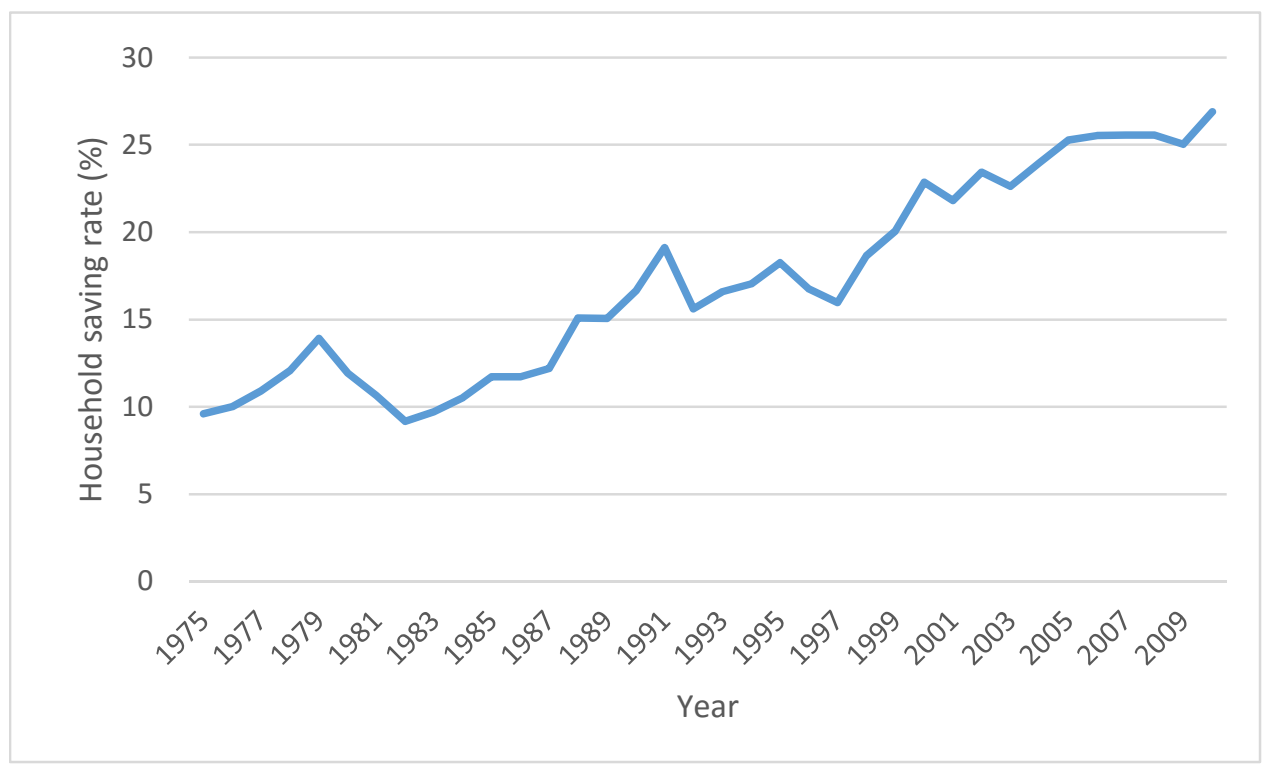

Figure 2-2: Trends over Time in the Household Saving Rate in Korea

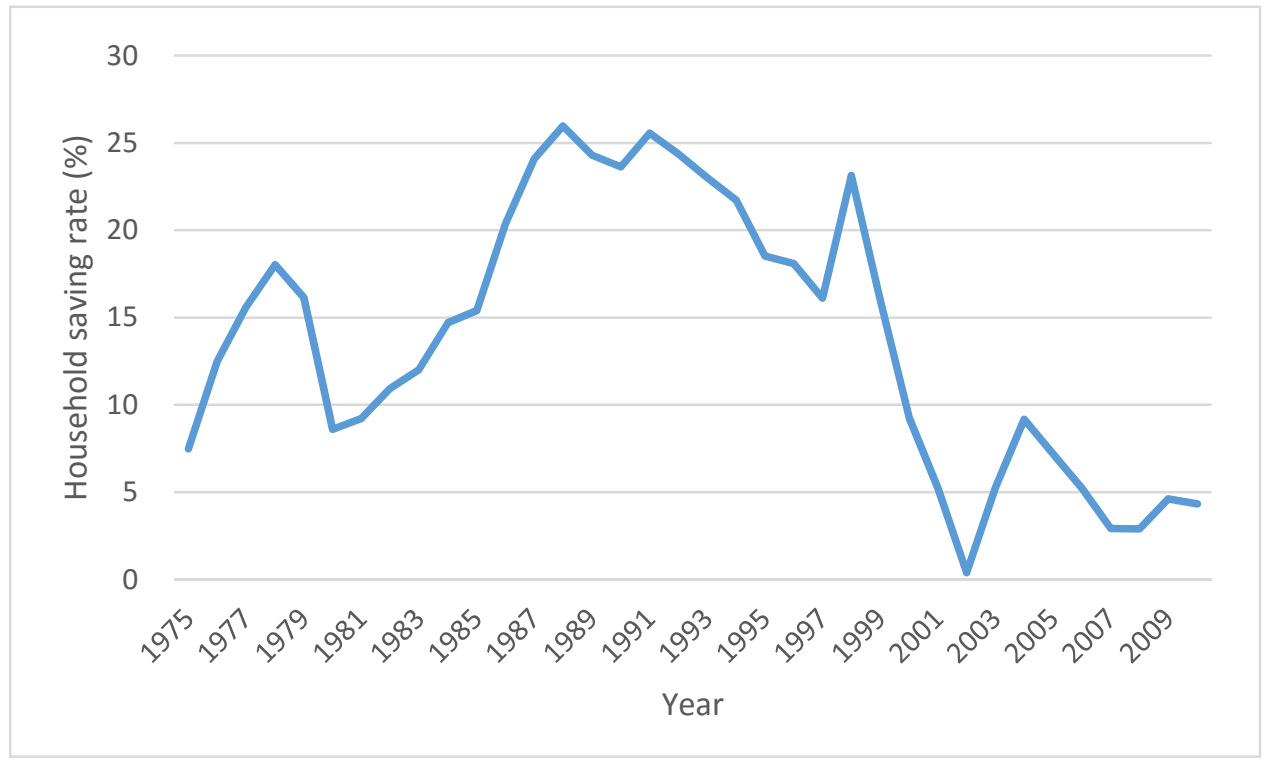

Notes: The household saving rate is computed as the ratio of net household saving to net disposable household income (in percent). The data are taken from Central Statistics Office (2016) in the case of India and Organisation for Economic Co-operation and Development (2016) in the case of Korea. 
Table 1-1: Results of Engle-Granger and KPSS Cointegration Tests for India

\begin{tabular}{|l|l|l|r|r|}
\hline \multicolumn{1}{|c}{ Specification } & Type of test & Time period & Number of obs & \multicolumn{1}{c|}{ Statistic } \\
\hline DEP, AGE, SEXRATIO, & DF & $1975-2010$ & 35 & $-3.389^{* *}$ \\
\hline & ADF & & 34 & $-2.757^{*}$ \\
\hline & ADF(2) & $1976-2010$ & 33 & $-3.082^{* *}$ \\
\hline & KPSS0 & $1977-2010$ & 35 & 0.0846 \\
\hline & KPSS1 & $1976-2010$ & 34 & 0.0581 \\
\hline & KPSS2 & $1977-2010$ & 33 & 0.0476 \\
\hline DEP, AGE, SEXRATIO, & DF & $1975-2010$ & 35 & $-3.533^{* *}$ \\
\hline PCY, CORPSAV & ADF(1) & $1976-2010$ & 34 & $-2.773^{*}$ \\
\hline & ADF(2) & $1977-2010$ & 33 & $-3.088^{* *}$ \\
\hline & KPSS0 & $1975-2010$ & 35 & 0.083 \\
\hline & KPSS1 & $1976-2010$ & 34 & 0.0583 \\
\hline & KPSS2 & $1977-2010$ & 33 & 0.048 \\
\hline
\end{tabular}

Notes: This table shows the results of Engle-Granger and KPSS tests for cointegration for India. Refer to the main text for variable definitions, data sources, and details on these tests. *, **, and *** denote significance at the 10,5 , and 1 percent levels, respectively. 
Table 1-2: Results of Engle-Granger and KPSS Cointegration Tests for Korea

\begin{tabular}{|c|c|c|c|c|}
\hline Specification & Type of test & Time period & Number of obs. & Statistic \\
\hline \multirow[t]{6}{*}{$\begin{array}{l}\text { DEP, AGE, SEXRATIO, } \\
\text { PCY }\end{array}$} & DF & $1976-2010$ & 35 & $-2.933^{*}$ \\
\hline & $\mathrm{ADF}(1)$ & $1977-2010$ & 34 & $-3.130 * *$ \\
\hline & $\mathrm{ADF}(2)$ & $1978-2010$ & $33^{\prime}$ & -2.522 \\
\hline & KPSS0 & $1976-2010$ & 35 & 0.227 \\
\hline & KPSS1 & $1977-2010$ & 34 & 0.143 \\
\hline & KPSS2 & $1978-2010$ & 33 & 0.119 \\
\hline \multirow[t]{6}{*}{$\begin{array}{l}\text { DEP, AGE, SEXRATIO, } \\
\text { PCY, CORPSAV }\end{array}$} & DF & $1976-2010$ & 35 & $-3.498^{* *}$ \\
\hline & $\mathrm{ADF}(1)$ & $1977-2010$ & 34 & $-3.569^{* *}$ \\
\hline & $\mathrm{ADF}(2)$ & $1978-2010$ & 33 & $-3.340^{* * *}$ \\
\hline & KPSS0 & $1976-2010$ & $35^{\prime \prime}$ & 0.156 \\
\hline & KPSS1 & $1977-2010$ & 34 & 0.106 \\
\hline & KPSS2 & $1978-2010$ & $33^{\prime}$ & 0.094 \\
\hline \multirow[t]{6}{*}{$\begin{array}{l}\text { DEP, AGE, PCY, } \\
\text { SEXRATIO, POP1519 }\end{array}$} & $\mathrm{DF}$ & $1976-2010$ & 35 & 0.094 \\
\hline & $\mathrm{ADF}(1)$ & $1977-2010$ & 34 & $-4.975 * * *$ \\
\hline & $\mathrm{ADF}(2)$ & $1978-2010$ & 33 & $-5.267 * * *$ \\
\hline & KPSS0 & $1976-2010$ & 35 & 0.0382 \\
\hline & KPSS1 & $1977-2010$ & 34 & 0.0291 \\
\hline & KPSS2 & $1978-2010$ & 33 & 0.0306 \\
\hline \multirow[t]{6}{*}{$\begin{array}{l}\text { DEP, AGE, SEXRATIO, } \\
\text { PCY, POP1519, CORPSAV }\end{array}$} & DF & $1976-2010$ & 35 & $-3.938 * * *$ \\
\hline & $\mathrm{ADF}(1)$ & $1977-2010$ & 34 & $-5.368^{* * *}$ \\
\hline & $\mathrm{ADF}(2)$ & $1978-2010$ & 33 & $-4.595^{* * *}$ \\
\hline & KPSS0 & $1976-2010$ & 35 & 0.0465 \\
\hline & KPSS1 & $1977-2010$ & 34 & 0.0342 \\
\hline & KPSS2 & $1978-2010$ & 33 & 0.0363 \\
\hline
\end{tabular}

Notes: This table shows the results of Engle-Granger and KPSS tests for cointegration for Korea. Refer to the main text for variable definitions, data sources, and details on these tests. * ${ }^{* *}$, and ${ }^{* * *}$ denote significance at the 10,5 , and 1 percent levels, respectively. 


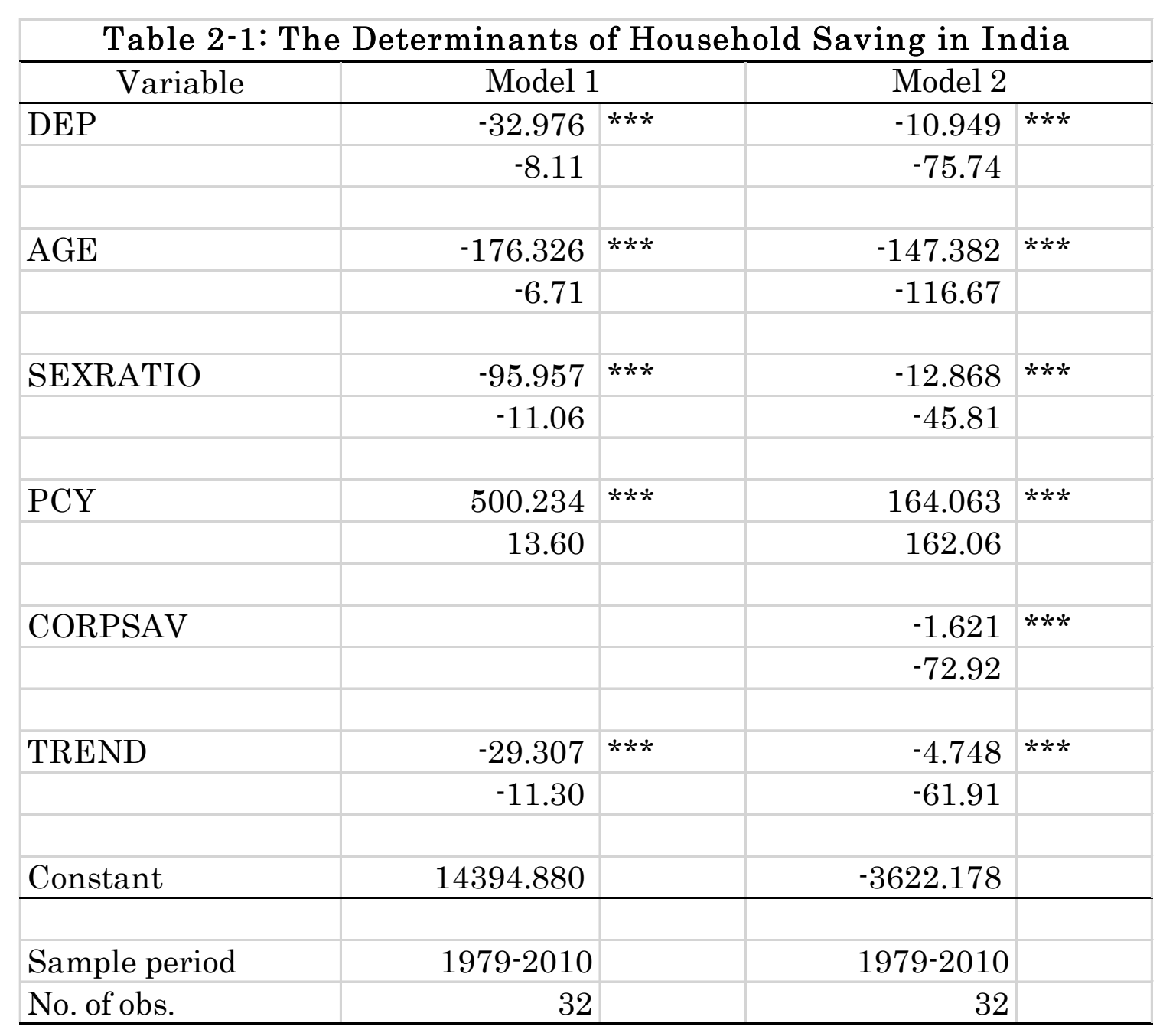

Notes: This table shows the cointegrating vector estimated using the Johansen method with 4 lags. The dependent variable is the household saving rate. Refer to the main text for variable definitions and data sources. * **, and *** denote significance at the 10 , 5 , and 1 percent levels, respectively. 
Table 2-2: The Determinants of Household Saving in Korea

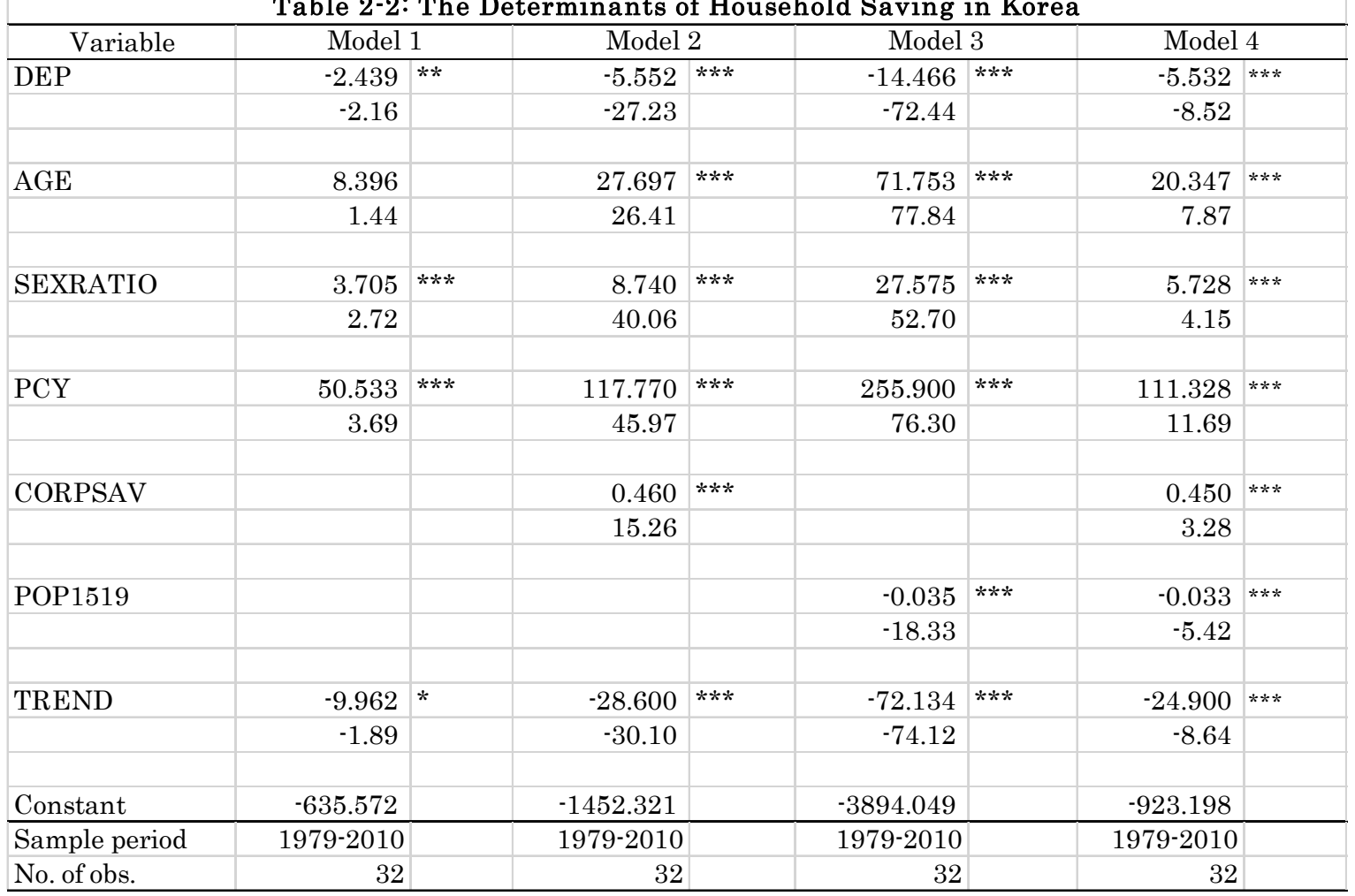

Notes: This table shows the cointegrating vector estimated using the Johansen method with 4 lags. The dependent variable is the household saving rate. Refer to the main text for variable definitions and data sources. * **, and *** denote significance at the 10 , 5 , and 1 percent levels, respectively. 